\title{
The pathophysiological significance of red blood cell nitric oxide concentrations in inflammatory Behçet's disease
}

\author{
Cem Evereklioglu ${ }^{1, C A}$, Mustafa Çekmen ${ }^{2}$, \\ Abdullah Özkiriş ${ }^{1}$, Levent Karabaş ${ }^{2}$ and \\ Mustafa Çaliş ${ }^{3}$
}

${ }^{1}$ Department of Ophthalmology, Erciyes University Medical Faculty, Kayseri, Turkey; and ${ }^{2}$ Department of Biochemistry, Kocaeli University Medical Faculty, Kocaeli, Turkey; and ${ }^{3}$ Department of Physical Medicine and Rehabilitation, Erciyes University Medical Faculty, Kayseri, Turkey

\author{
${ }^{\mathrm{CA}}$ Corresponding Author \\ Home address: Sivas Cad. Cebeci Apt. A-Blok. 175/15, \\ TR-38020, Kayseri, Turkey \\ Tel: +903522358265 \\ Fax: + 903522358365 \\ E-mail: evereklioglu@hotmail.com \\ Personal webpage: http://evereklioglu.8m.com
}

Nitric oxide $\left(\mathrm{NO}^{\bullet}\right)$ is a free oxygen radical with powerful vasodilator properties studied in many tissues. It is produced by $\mathrm{NO}^{\bullet}$ synthases in endothelial cells upon stimulation by various agents like cytokines and tumor necrosis factor. The end-products of $\mathrm{NO}^{\bullet}$ are nitrite and nitrate. Their levels are used biochemically to determine $\mathrm{NO}^{\bullet}$ synthase activity. Evidence is accumulating for the role of $\mathrm{NO}^{\bullet}$ in the pathophysiology of inflammatory Behçet's disease (BD). Indeed, we first demonstrated that serum $\mathrm{NO}^{\bullet}$ production is increased in active $\mathrm{BD}$, suggesting a possible new activity marker. ${ }^{1}$ More recently, we have reported that pro-inflammatory cytokines, inducers of $\mathrm{NO}^{\bullet}$, and lipid peroxidation are increased and associated with decreased antioxidant enzyme activities in BD. ${ }^{2,3}$ Our findings were then supported by four independent investigations, one of which was from the present group. ${ }^{4-7}$ Moreover, aqueous humor $\mathrm{NO}^{\bullet}$ levels were found to be increased in uveitic BD patients. ${ }^{8}$ Furthermore, Salvarani et al. ${ }^{9}$ have recently shown that the GluAsp298 polymorphism of endothelial $\mathrm{NO}^{\bullet}$ synthase gene is associated with BD susceptibility. Therefore, to support our previous studies, this report further investigated for the first time $\mathrm{NO}^{\bullet}$ levels in red blood cells of BD patients compared with age-matched and sex-matched healthy control volunteers.

A total of 20 patients with BD (16 men, four women), with a mean age of 33.4 years, and 15 healthy control subjects (12 men, three women), with a mean age of 32.1 years, were enrolled in this study. Patients with BD had to fulfil the International Study Group criteria for the diagnosis of BD. ${ }^{10}$

Fasting whole-blood samples were taken from BD patients and control subjects by venipuncture from an antecubital peripheral vein into heparinised plain tubes to prepare the erythrocyte sediment. The buffy coat on the erythrocyte sediment was carefully separated. The erythrocyte sediment was subsequently washed three times with 10-fold volumes of $0.9 \%$ sodium chloride solution to remove the plasma remnants. Following this, the erythrocyte sediment was treated with four-fold volumes of ice-cold deionised water to obtain hemolysate. $\mathrm{NO}^{\bullet}$ is a labile compound and has a brief half-life, and therefore its detection as the native $\mathrm{NO}^{\bullet}$ molecule is difficult. It is rapidly converted to the stable end-products nitrate $\left(\mathrm{NO}_{3}^{-}\right)$and nitrite $\left(\mathrm{NO}_{2}^{-}\right)$in typical oxygenated aqueous solutions and tissues. Thus, erythrocyte total nitrite levels were measured as an index of $\mathrm{NO}^{\bullet}$ production. For total nitrite detection, lysate was treated with copperised cadmium in glycine buffer at $\mathrm{pH} 9.7$ (2.5-3.0 g of cadmium granules for a $4 \mathrm{ml}$ reaction mixture) to reduce $\mathrm{NO}_{3}^{-}$to $\mathrm{NO}_{2}^{-} \cdot{ }^{11}$ Measurement of total nitrite was based on the Griess reaction, in which a chromofore with a strong absorbance at $540 \mathrm{~nm}$ is formed by the reaction of nitrite with a mixture of sulphanilamide and $\mathrm{N}$-(1- 
naphthyl)-ethylenediamine. A standard curve was established with a set of serial dilutions $\left(10^{-8}\right.$ to $10^{-3} \mathrm{~mol} / \mathrm{l}$ ) of sodium nitrite.

The analysis was performed by the same examiner (M.C..), who was blinded to diagnosis, and was assayed in duplicate. Data were presented as nanomoles per gram of hemoglobin (Hb) (mean \pm standard deviation). The Mann-Whitney U-test was used for statistical analysis and $p<0.05$ was considered significant. BD patients had significantly $(p<0.001)$ higher erythrocyte $\mathrm{NO}{ }^{\bullet}$ concentrations $(179.7 \pm 33.6$ $\mathrm{nmol} / \mathrm{g} \mathrm{Hb})$ when compared with control subjects $(129.7 \pm 23.4 \mathrm{nmol} / \mathrm{g} \mathrm{Hb})$. The significantly increased $\mathrm{NO}^{\bullet}$ levels in erythrocytes from BD patients indicated a role of $\mathrm{NO}^{-}$in the pathogenesis of this unique disorder.

$\mathrm{NO}^{\bullet}$ is an important intercellular physiological messenger of immunity and inflammation for the vascular system, with the inhibition of platelet adhesion. ${ }^{12}$ It is produced by various cell types including the endothelium to facilitate communication. The formation of $\mathrm{NO}^{\bullet}$ is catalysed by $\mathrm{NO}^{\bullet}$ synthase, an enzyme present in a variety of cell types including red blood cells, which can be induced by cytokines during inflammatory and infectious processes, resulting in large amounts of $\mathrm{NO}^{\bullet}$ production. ${ }^{11,13}$ In addition, $\mathrm{NO}^{-}$is accepted as an oxygen radical and also recognised as a major messenger molecule involved in the regulation of vasodilatation.

$\mathrm{NO}^{\bullet}$ is present in the blood at $10^{-7} \mathrm{M}$ under physiological conditions, but at concentrations higher than $10^{-6} \mathrm{M}$ during inflammatory disease states. ${ }^{14}$ Because the erythrocyte membrane is highly permeable to $\mathrm{NO}^{\circ}$, it is quickly scavenged by $\mathrm{Hb}$ in red blood cells when $\mathrm{NO}^{\bullet}$ is released into the bloodstream or oxidised to nitrite. ${ }^{15}$ Nitrite can also enter erythrocytes rapidly and reacts with oxyhemoglobin but does not exert a strong oxidant stress on these cells. Peroxynitrite anion, the reactive species formed in vivo by the reaction of $\mathrm{NO}^{\bullet}$ with the superoxide anion, is also capable of diffusing across erythrocyte membranes via anion channels and passive diffusion. ${ }^{16}$ Moreover, recent studies have revealed that human erythrocytes possess a NO ${ }^{\bullet}$ synthase. Therefore, we think that excess $\mathrm{NO}^{\bullet}$ levels found in this study may be liberated from the endothelium of conductance and vessels in inflammatory BD, which is then taken up by red blood cells, and/or NO ${ }^{\bullet}$ may be produced primarily in the erythrocytes by the enzyme $\mathrm{NO}^{\bullet}$ synthase.

Excess $\mathrm{NO}^{\bullet}$, in turn, may cause lipid peroxidation, cellular dysfunction and death. Indeed, we demonstrated the presence of strong pro-oxidants (radicals) during the course of $\mathrm{BD}$, suggesting the presence of an imbalance in the oxidant-antioxidant system in the pathogenesis of $\mathrm{BD} .{ }^{1-3}$ In other words, because $\mathrm{NO}^{\bullet}$ participates in the compensatory response to chronic vascular injury, ${ }^{14}$ its increased levels seem to be pathophysiologically significant during the course of this unique vasculitic disorder. Moreover, these results are consistent with the hypothesis that $\mathrm{NO}^{\bullet}$ may have a crucial role in vasoregulatory mechanisms in BD patients. ${ }^{1,5}$ Likewise, cytokine-induced overproduction of $\mathrm{NO}^{\bullet}$ by immunocompetent cells may be the other possible pathophysiological consequences with subsequent development of oxidative stress in $\mathrm{BD}$. Therefore, the present finding indicates $\mathrm{NO}^{\bullet}$-dependent alterations of oxidative metabolic burst in such patients, and also questions the possible participation of erythrocytes during the course of inflammation in BD. In other words, $\mathrm{NO}^{*}-$ $\mathrm{Hb}$ may serve as a store of $\mathrm{NO}^{\bullet}$ in red blood cells, and oxidative stress status in the blood seems to be deteriorated as a whole in $\mathrm{BD}$, both in plasma and erythrocytes, confirming an impaired oxidant-antioxidant equilibrium.

ACKNOWLEDGEMENTS. The authors have no financial or proprietary interest in any instrument or products used in this study.

\section{References}

1. Evereklioglu $\mathrm{C}$, Turkoz $\mathrm{Y}, \mathrm{Er} \mathrm{H}$, Inaloz HS, Ozbek E, Cekmen M Increased nitric oxide production in patients with Behçet's disease: is it a new activity marker? J Am Acad Dermatol 2002; 46: 50-54.

2. Evereklioglu C, Er H, Turkoz Y, Cekmen M. Serum levels of TNF-(, sIL2R, IL-6, and IL-8 are increased and associated with elevated lipid peroxidation in patients with Behçet's disease. Mediats Inflamm 2002; 11: $87-93$.

3. Erkilic K, Evereklioglu C, Cekmen M, Ozkiris A, Duygulu F, Dogan H. Adenosine deaminase enzyme activity is increased and negatively correlates with catalase, superoxide dismutase and glutathione peroxidase in patients with Behcet's disease: original contributions/clinical and laboratory investigations. Mediats Inflamm 2003; 12: 107-116.

4. Kiraz S, Ertenli I, Calguneri M, et al. Interactions of nitric oxide and superoxide dismutase in Behçet's disease. Clin Exp Rheumatol 2001; 19: S25-S29.

5. Er H, Evereklioglu C, Cumurcu T, Turkoz Y, Ozerol E, Sahin K, Doganay $\mathrm{S}$. Serum homocysteine level is increased and correlated with endothelin-1 and nitric oxide in Behçet's disease. BrJ Ophthalmol 2002; 86: 653-657.

6. Atalay G, Eksioglu-Demiralp E, Akoglu T, Direskeneli H. The effects of nitric oxide donors and inhibitors on neutrophil functions in Behcet's disease. Clin Exp Rheumatol 2002; 20: 17-20.

7. Sancak B, Onder M, Oztas MO, Bukan N, Gurer MA. Nitric oxide levels in Behcet's disease. J Eur Acad Dermatol Venereol 2003; 17: 7-9.

8. Yilmaz G, Sizmaz S, Yilmaz ED, Duman S, Aydin P. Aqueous humor nitric oxide levels in patients with Behcet disease. Retina 2002; 22: $330-335$.

9. Salvarani C, Boiardi L, Casali B, et al. Endothelial nitric oxide synthase gene polymorphisms in Behcet's disease. J Rheumatol 2002; 29: 535 540

10. International Study Group for Behçet's Disease. Criteria for diagnosis of Behçet's disease. Lancet 1990; 335: 1078-1080.

11. Granger DL, Taintor RR, Boockvar KS, Hibbs Jr. JB. Measurement of nitrate and nitrite in biological samples using nitrate reductase and Griess reaction. Methods Enzymol 1996; 268: 142-151.

12. Farrell AJ, Blake DR. Nitric oxide. Ann Rheum Dis 1996; 55: 7-20.

13. Moshage $\mathrm{H}$. Nitric oxide determinations: much ado about NO.-thing? Clin Chem 1997; 43: 553-556.

14. Mesquita R, Picarra B, Saldanha C, Martins e Silva J. Nitric oxide effects on human erythrocytes structural and functional properties-an in vitro study. Clin Hemorbeol Microcirc 2002; 27: 137-147.

15. May JM, Qu ZC, Xia L, Cobb CE. Nitrite uptake and metabolism and oxidant stress in human erythrocytes. Am J Physiol Cell Physiol 2000; 279: $1946-1954$

16. Denicola A, Souza JM, Radi R. Diffusion of peroxynitrite across erythrocyte membrane. Proc Natl Acad Sci USA 1998; 95: 3566-3571.

\section{Received 12 May 2003}

Accepted 26 May 2003 


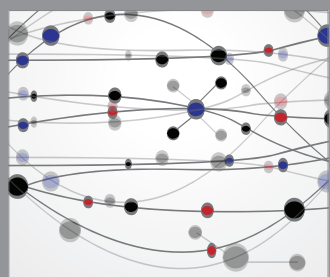

The Scientific World Journal
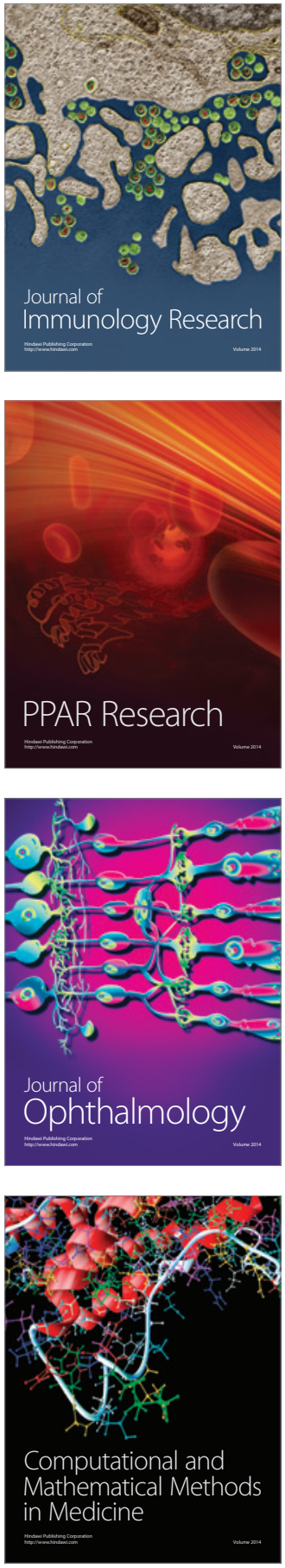

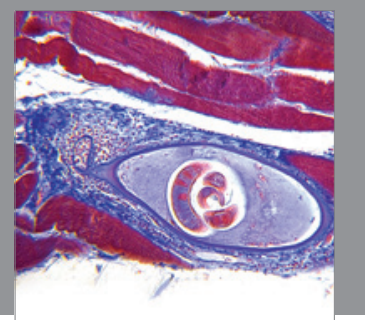

Gastroenterology

Research and Practice
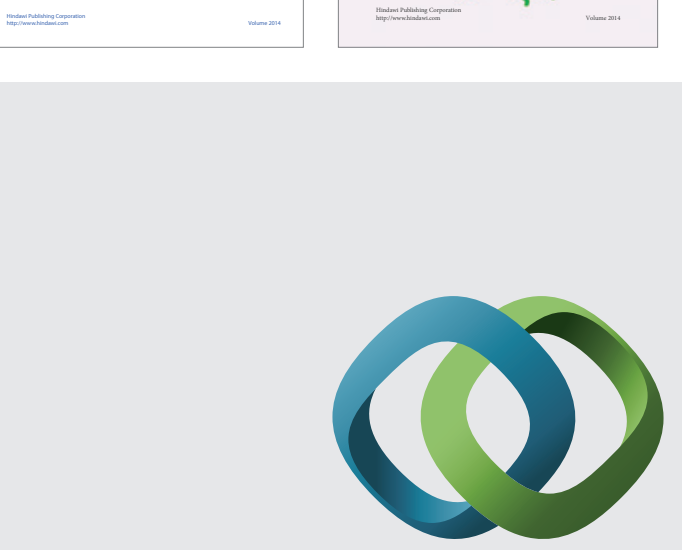

\section{Hindawi}

Submit your manuscripts at

http://www.hindawi.com
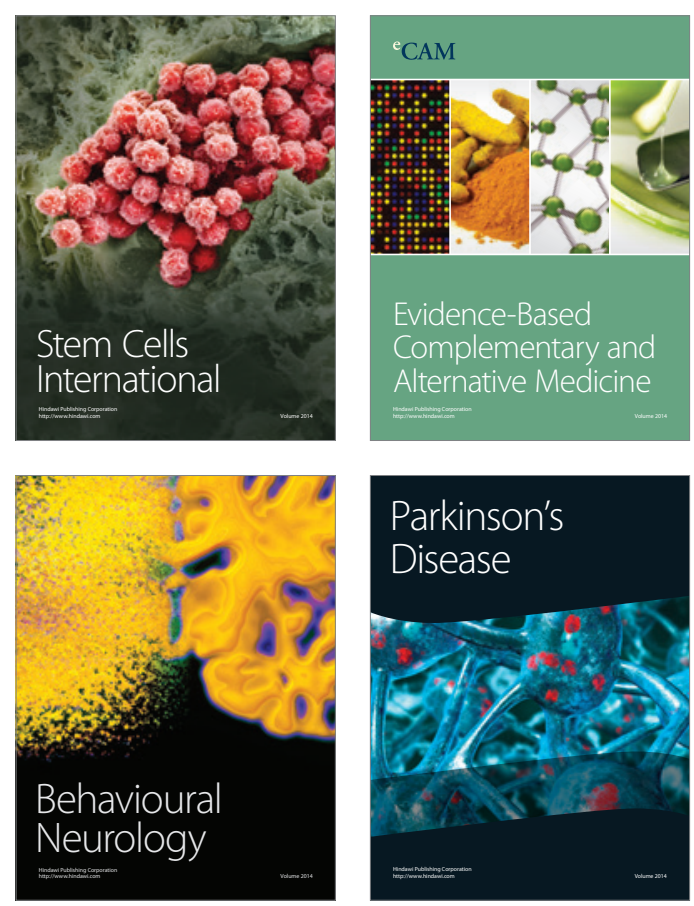

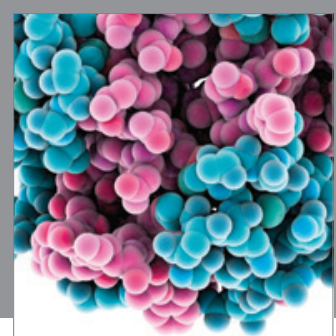

Journal of
Diabetes Research

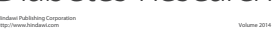

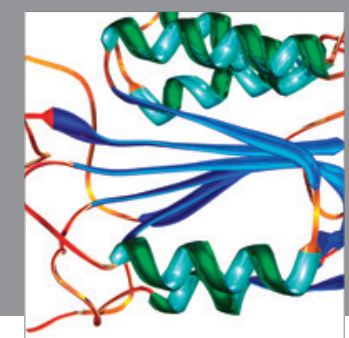

Disease Markers
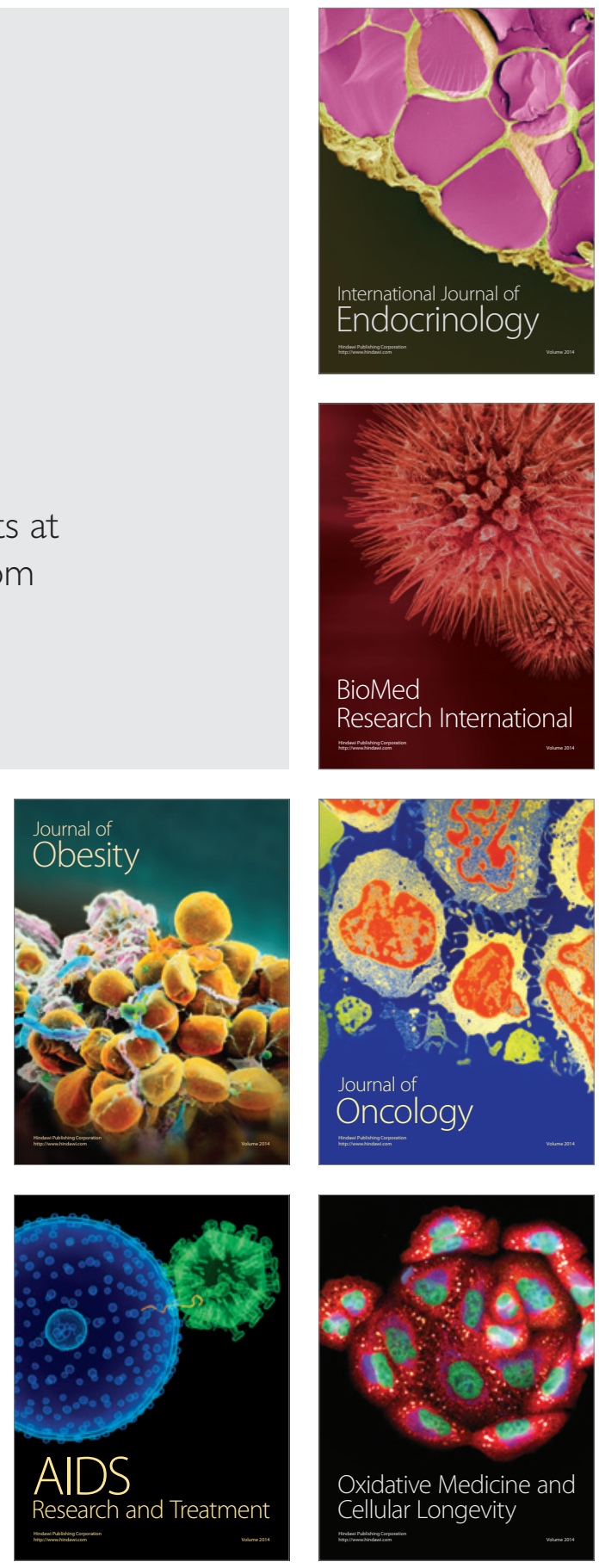